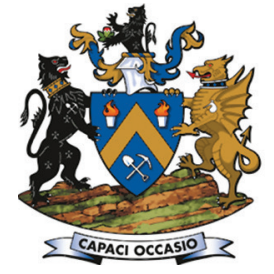

\title{
Using experimental design and response surface methodology (RSM) to optimize gold extraction from refractory sulphidic gold tailings with ionic liquids
}

\author{
S. Teimouri1 ${ }^{1}$, G. Mawire ${ }^{1}$, J.H. Potgieter ${ }^{1,2}$, G.S. Simate ${ }^{1}$, L. van Dyk ${ }^{1}$, \\ and M. Dworzanowski ${ }^{1}$
}

Affiliation:

${ }^{1}$ School of Chemical and Metallurgical Engineering, University of the Witwatersrand Johannesburg, South Africa.

2 Department of Natural Science, Manchester Metropolitan University, Manchester, UK

Correspondence to:

S. Teimouri

Email:

tsimon1368@gmail.com 1630835@students.wits.ac.za

Dates:

Received: 12 Dec. 2019

Revised: 19 May 2020

Accepted: 1 Jul. 2020

Published: July 2020

How to cite:

Teimouri, S., Mawire, G.

Potgieter, J.H., Simate, G.S.,

van Dyk, L., and

Dworzanowski, M.

Using experimental design and response surface methodology

(RSM) to optimize gold extraction from refractory sulphidic gold

tailings with ionic liquids.

The Southern African Institute of Mining and Metallurgy

\section{DOI ID:}

http://dx.doi.org/10.17159/24119717/1068/2020

ORCiD ID:

S. Teimouri

https://orchid.org/0000-0003-

2511-8040

J.H. Potgieter

https://orchid.org/0000-00032833-7986

G.S. Simate

https://orchid.org/0000-0001-

9447-2663

L. van Dyk

https://orchid.org/0000-0003-

2436-9710

\section{Synopsis}

This work examined the feasibility of gold extraction from a pyrite flotation concentrate sample using an ionic liquid and water mixture as solvent, thiourea complexing agent, and iron(III) sulphate oxidant. A design of experiment (DOE) methodology was used to optimize the process parameters. The purpose of the investigation was to determine how feasible it would be to replace the traditional cyanide extraction process by using an alternative approach, and compare the yield that could be obtained with a less environmentally damaging and hazardous combination of chemicals. Test parameters such as ionic liquid concentration, pulp density, time, and temperature were varied using two imidazolium-based ionic liquids: 1-butyl-3-methylimidazolium hydrogen sulphate $\left[\mathrm{Bmim}^{+} \mathrm{HSO}_{4}^{-}\right]$and 1-butyl-3-methylimidazolium trifluoromethansulphonate $\left[\mathrm{Bmim}^{+} \mathrm{CF}_{3} \mathrm{SO}_{3}^{-}\right]$. The effects on gold extraction were assessed and screened using a half fractional factorial design $\left(2^{5-1}\right)$ approach. The ionic liquid concentration, pulp density, and temperature had a statistically significant effect on gold extraction, while the type of ionic liquid and extraction time did not affect the gold extraction as much within the operating range investigated. A high gold extraction was obtained at low ionic liquid concentration, low pulp density, and high temperature. A central composite design in conjunction with response surface methodology were used to create an optimization design with the statistically significant parameters in an attempt to establish the optimal gold extraction conditions. It was found that the optimum concentration of ionic liquid $\left[\mathrm{Bmim}^{+} \mathrm{HSO}_{4}^{-}\right]$in the aqueous solution was $15 \%(\mathrm{v} / \mathrm{v})$, pulp density was $15 \%(\mathrm{w} / \mathrm{v})$, and the temperature $60^{\circ} \mathrm{C}$, with a gold extraction of $35.7 \%$ under these conditions. This, sadly, was only about half of the yield achieved with the cyanide process. In order to compete with the traditional approach, a way will have to be found to completely destroy the pyrite component in the material, in which a substantial portion of the gold was locked up. This work, and similar studies reported in the literature, indicates that cyanide technology for gold recovery will remain the process of choice in the gold industry for the immediate future.

\section{Keywords}

refractory sulphidic gold tailings, gold leaching, ionic liquids, design of experiment (DOE), screening, optimization.

\section{Introduction}

The general decline in resources of gold ore grades at shallow depths has in recent years resulted in the exploration of gold tailings to recover gold to meet demand. Gold tailings are predominantly refractory and are not amenable to efficient gold recovery with conventional methods. This has led to a growing interest in research into alternative extraction techniques.

Gold tailings are classified as secondary ores, and are leftover materials discharged after an extraction process. Mine tailings are an environmental burden that contains precious metals such as gold, but further treatment of the tailings and improving the gold recovery has the potential to offer massive financial rewards (Falagán, Grail, and Johnson, 2017). DRDGOLD (Pty) Ltd feed ore originates from surface tailings, sand dumps, and slime dams left behind by mining operations across the Witwatersrand Basin. Organic material and debris are removed from the slurry before it is fed to a flotation circuit, where preferential recovery of pyrite over quartz produces a sulphide-enriched gold concentrate. 


\section{Using experimental design and response surface methodology (RSM) to optimize gold}

Within the gangue matrix, gold is finely disseminated in the host sulphide minerals, making it inaccessible for extraction (Attia and El-Zeky, 1989). Uneconomical reagent consumption and complex pre-treatment processes are characteristic of sulphide-gold bearing ores, including gold tailings, with the major drawback being the substantial risks associated with the cyanidation process (Grosse et al., 2003). There is thus a need to find an alternative, efficient lixiviant for gold recovery from refractory sulphidic minerals.

Ionic liquids (ILs) are prospective alternative solvents that are composed mainly of organic cations and organic/inorganic anions. ILs are salts that exist as liquids at ambient conditions because of their low melting point and low vapour pressure. Some of the properties that make ILs favourable as alternative solvents are non-flammability, chemical and thermal stability, high conductivity, wide electrochemical windows, and the ability to be task-specified (Lee, 2012; Park et al., 2014).

A number of studies have been carried out on the use of ILs as an efficient lixiviant for gold extraction and recovery. Whitehead, Lawrance, and McCluskey (2004) investigated the extraction of gold and silver from a sulphidic ore using aqueous $\mathrm{H}_{2} \mathrm{SO}_{4}$ and 1-butyl-3-methylimidazolium hydrogen sulphate $\left[\mathrm{Bmim}^{+} \mathrm{HSO}_{4}^{-}\right]$as a nonconventional solvent with thiourea and iron(III) sulphate as the complexing agent and oxidant, respectively. Silver extraction was improved significantly in the ionic liquid system $(>60 \%$, compared to $<10 \%$ in the aqueous sulphuric acid system), although gold extraction was relatively similar (>85\%) in both systems.

Many experimental investigations involve the study of various effects, and experiments in which one factor at a time is changed are inefficient, uneconomical, and do not show the entire interaction. Full and fractional factorial experiments are the only means to completely and systematically study interactions between factors. This allows screening tests to be done so that one can work with just the significant factors, which can be optimized to solve problems of low recoveries successfully (Simate, Ndlovu, and Gericke, 2009). For example, Aguirre et al. (2016) used response surface methodology (RSM) to establish the optimal conditions for $\mathrm{Cu}$ extraction from chalcopyrite $\left(\mathrm{CuFeS}_{2}\right)$ with $\left[\mathrm{Bmim}^{+} \mathrm{HSO}_{4}^{-}\right]$as the lixiviant. Shemi et al. (2013) employed an experimental design approach (DOE) to optimize influential factors in aluminium extraction from coal fly ash. RSM is one of the popular methods used to establish the optimal conditions by using a fitted quadratic polynomial model of the experimental results and was applied after the screening stage (Montgomery, 1984).
Figure 1 represents the sequential steps in the design of experiments employed in this study. For screening, a fractional factorial design (i.e., $2^{5-1}$ ) was used to investigate the influence of the concentration of IL, pulp density, time, and temperature with two imidazolium-based ILs, so as to identify the statistically significant parameters that have a large effect on gold extraction. Afterwards, the statistically significant parameters were optimized through CCD in conjunction with RSM.

\section{Material and methods}

\section{Mineral tailings and characterization}

The sample was obtained from the ERGO plant, operated by DRDGOLD (Pty) Ltd, in South Africa. Most of the gold in the ERGO plant feed (tailings) is associated with sulphide minerals, which justifies the preferential concentration of pyrite over other minerals resulting in a pyrite flotation concentrate. This flotation concentrate sample contained a high amount of sulphides, with micro-disseminated gold mostly locked in the pyrite fraction. The gold grade was $2.38 \mathrm{~g} / \mathrm{t}$. A photomicrograph indicating the gold occurrence in both the free as well as the locked state in the pyrite fraction is shown in Figure 2. This sample can be classified

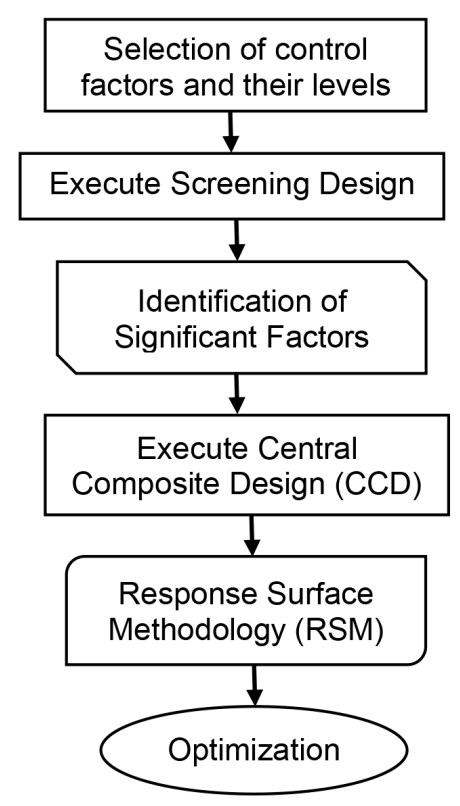

Figure 1-Sequential steps of DOE methodology
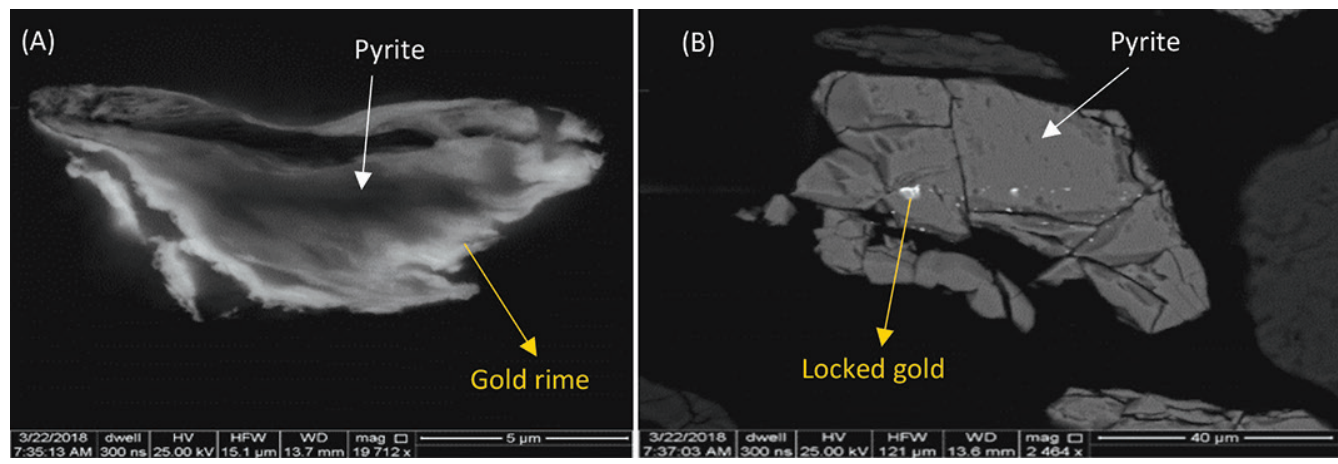

Figure 2-Gold association with pyrite: (A) gold rim around pyrite, (B) gold locked in pyrite 


\section{Using experimental design and response surface methodology (RSM) to optimize gold}

as refractory as gold was occluded within the crystal matrix of a mineral and/or various minerals, making it inaccessible for leaching. Figure 3 presents the liberation by grade of the finely milled flotation concentrate sample. Gold recovery from by carbon in leach (CIL) and carbon in pulp (CIP) after fine grinding was approximately $67 \%$.

The as-received pyrite flotation concentrate was collected before the fine grinding step. The sample was milled with a laboratory roller ball mill, since it was agglomerated and included solid hard lumps. The subsequent fine material was dried in an oven at $105^{\circ} \mathrm{C}$ to remove any moisture. The dried sample was then blended and classified into different fraction sizes $(-45 \mu \mathrm{m},+45$ $-90 \mu \mathrm{m},+90-106 \mu \mathrm{m}$, and $+106-150 \mu \mathrm{m})$ using an electronic sieve shaker (Eriez model ES 200) with stainless steel sieves. The finest size fraction $(-45 \mu \mathrm{m})$ was selected for the leaching experiments to ensure a sufficient exposed surface area, and it can be represented by the $+25 \mu$ m cumulative plot (Figure 3 ). Another reason was to ensure a high concentration of gold in the material so that small changes in response to varying the different test parameters could be detected.

It is well known that hydrometallurgical processes, and leaching in particular, are absolutely dependent on the shrinking core model, liberation, and particle size distribution (PSD). The leaching kinetics of the selected size fraction was described in detail recently by Teimouri et al. (2020), who established that there were two regions of kinetic control, i.e. mixed control and diffusion control, with activation energies $E_{a}$ of $17.97 \mathrm{~kJ} / \mathrm{mol}$ and $27.17 \mathrm{~kJ} / \mathrm{mol}$, respectively.

The $-45 \mu \mathrm{m}$ fraction, which was used in this investigation, was analysed by both atomic absorption spectroscopy (AAS) and fire assay. The results were within $2.5 \%$ relative standard deviation (RSD) for the value of $2.84 \mathrm{~g} / \mathrm{t}$ determined via gold assay. Table I shows the mineralogical analysis of the flotation concentrate sample by X-ray diffraction (XRD). The predominant minerals were quartz and pyrite at $45.1 \%$ and $36.3 \%$, respectively. Figure 4 illustrates the XRD scan of the concentrate.

\section{Reagents}

The two ILs, 1-butyl-3-methyl-imidazolium hydrogen sulphate $\left[\mathrm{Bmim}^{+} \mathrm{HSO}_{4}^{-}\right]$and 1-butyl-3-methylimidazolium trifluoromethansulphonate $\left[\mathrm{Bmim}^{+} \mathrm{CF}_{3} \mathrm{SO}_{3}{ }^{-}\right]$, were chosen, with thiourea $\mathrm{SC}\left(\mathrm{NH}_{2}\right)_{2}$ as complexing agent and $\mathrm{Fe}_{2}\left(\mathrm{SO}_{4}\right)_{3}$ as a source of ferric ions, which acted as the oxidant. All the chemicals and reagents were purchased from Sigma Aldrich in South Africa and were of analytical grade, and used as received without further purification.

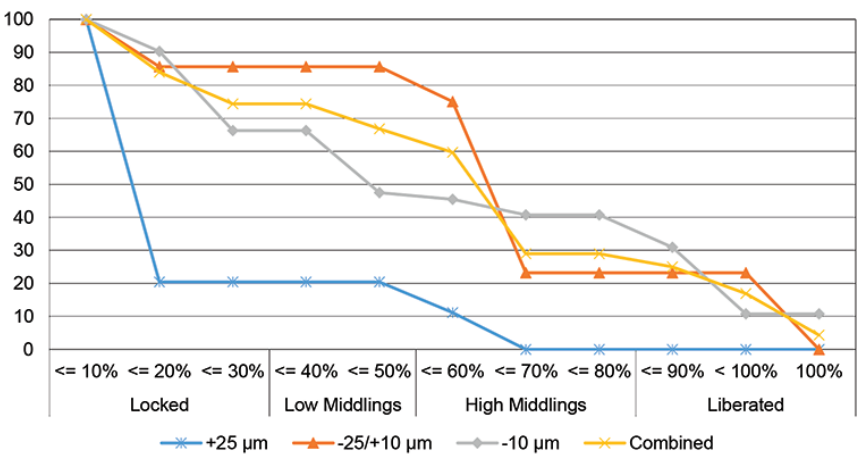

Figure 3-Liberation by grade (cumulative) for finely milled pyrite flotation concentrate

Table I

XRD analysis the flotation concentrate sample

\begin{tabular}{|l|c|c|}
\hline Mineral & Chemical formulae & Mass $\%$ \\
\hline Quartz & $\mathrm{SiO}_{2}$ & 45.1 \\
Pyrite & $\mathrm{FeS}_{2}$ & 36.3 \\
Muscovite & $\mathrm{KAl}_{2}\left(\mathrm{Si}_{3} \mathrm{Al} \mathrm{O}_{10}\left(\mathrm{OH}, \mathrm{F}_{22}\right.\right.$ & 5.3 \\
Chlorite & $\left(\mathrm{Mg}, \mathrm{Fe}^{2+}\right)_{5} \mathrm{AlSi}_{3} \mathrm{Al}_{2} \mathrm{O}_{10}(\mathrm{OH})_{8}$ & 4.1 \\
Pyrophyllite & $\mathrm{Al}_{2} \mathrm{Si}_{4} \mathrm{O}_{10}(\mathrm{OH})_{2}$ & 4.1 \\
Other & - & 5.0 \\
\hline
\end{tabular}

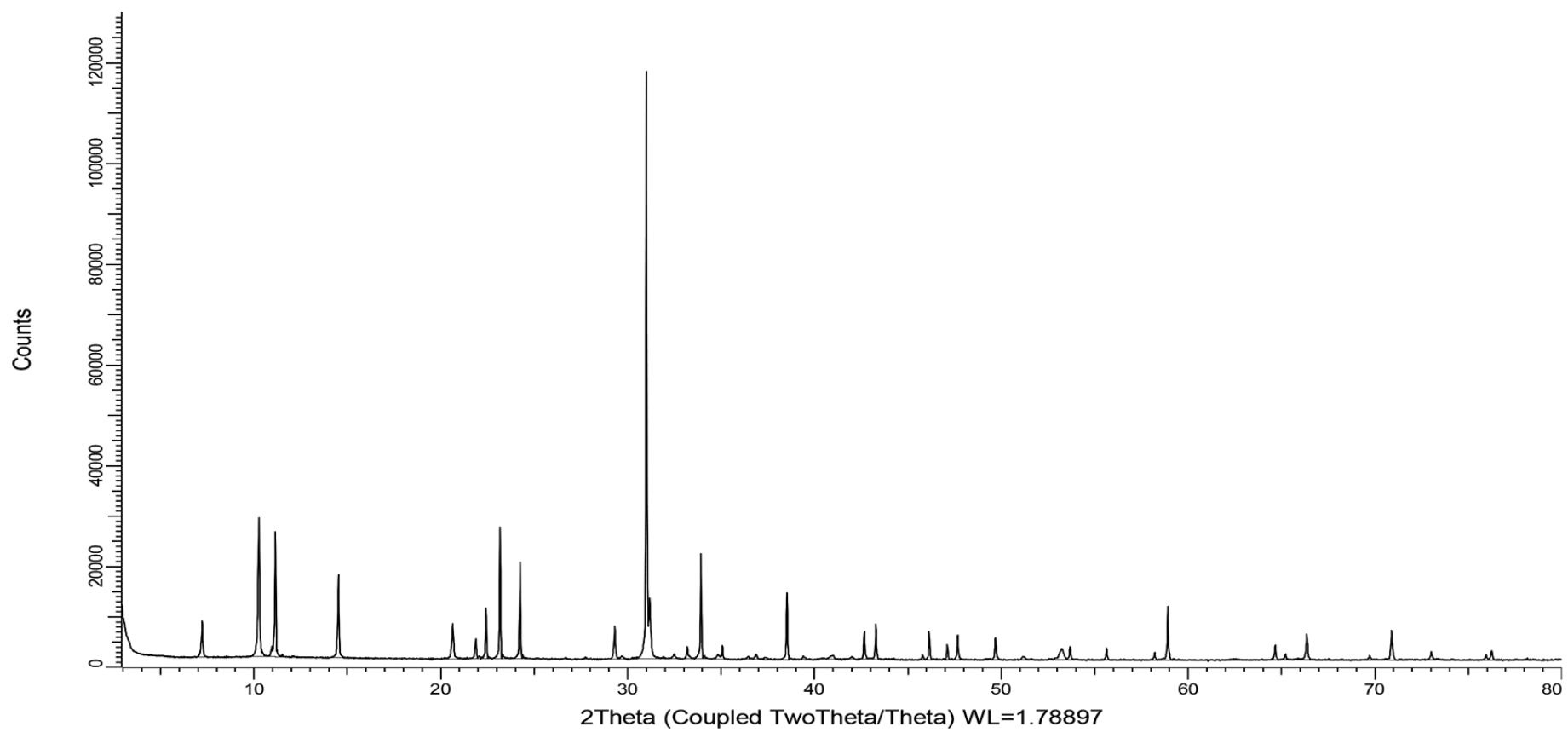

Figure 4-XRD spectrum of the flotation concentrate sample 


\section{Using experimental design and response surface methodology (RSM) to optimize gold}

\section{Design of experiments}

Design Expert software (version 11) was employed to study the feasibility of leaching of the flotation concentrate sample using the reagent suite; firstly, through screening of parameters and then by optimizing the statistically significant parameters.

\section{Factorial design}

The significance of each parameter and probable interactive effects were considered using a fractional factorial design (i.e., $2^{5-1}$, containing 20 experimental runs) represented in Table II, and the yield of gold was taken as the measured response. Previous studies (Whitehead, Lawrance, and McCluskey, 2004; Whitehead et al., 2007, 2009; Aguirre et al., 2016) on the leaching of sulphidic ores using ILs provided some guidelines when designing the experiments. Therefore, the choice of the parameters to investigate was based on reports in the literature. The design factors were categorized as controlled parameters and constant (uncontrolled) parameters. The controlled parameters were the selected parameters for the purpose of the study. The constant parameters ( $\mathrm{pH}$ and shaking speed) were those that may have an effect on the response, but were not of interest for the purpose of the study, and thus were held constant ( $\mathrm{pH}=1$ and shaking speed $=250 \mathrm{r} / \mathrm{min})$. The design controlled parameters, the coded levels (low $=-1$, centre $=0$, and high $=+1$ ) and the actual values are represented in Table III.

It is worthy of note that acidic conditions ( $\mathrm{pH} 1$ ) were chosen based on the reagents used. To avoid rapid degradation of thiourea, as well as to ensure the stability of thiourea, an acidic solution was required. In acidic medium, the aqueous form of thiourea acts as a ligand to form a stable cationic complex with gold. In addition, ferric ions are stable at $\mathrm{pH}<2$ and precipitate as hydroxyl species (ferric hydroxide) as the $\mathrm{pH}$ increases (Whitehead et al., 2007).
Table III

Experimental parameters and respective levels

\begin{tabular}{|l|c|c|c|}
\hline Parameter & Low level (-1) & Centre point (0) & High level (+1) \\
\hline IL type & {$\left[\mathrm{Bmim}^{+} \mathrm{SF}_{3} \mathrm{SO}_{3}^{-}\right]$} & {$\left[\mathrm{Bmim}+\mathrm{HSO}_{4}^{-}\right]$} & {$\left[\mathrm{Bmim}^{-} \mathrm{HSO}_{4}^{-}\right]$} \\
IL concentration & $33 \% \mathrm{IL}$ & $55.5 \% \mathrm{IL}$ & $78 \% \mathrm{IL}$ \\
Pulp density & $12.5 \%(1: 8)$ & $18.7 \%(1: 6)$ & $25 \%(1: 4)$ \\
Temperature & $35^{\circ} \mathrm{C}$ & $50^{\circ} \mathrm{C}$ & $65^{\circ} \mathrm{C}$ \\
Time & $17 \mathrm{~h}$ & $27.5 \mathrm{~h}$ & $38 \mathrm{~h}$ \\
\hline
\end{tabular}

\section{Methodology for data analysis}

\section{Normal probability plots of effects}

A normal probability plot is a plot of the effect of the actual value evaluations versus their accumulative normal probabilities, which offers an approach to select significant factors (Montgomery, 1984).

\section{Central composite design and response surface method- ology}

The CCD combined with RSM was used in this study to examine the optimal conditions of the statistically significant parameters for gold extraction from pyrite flotation concentrate.

A second-order polynomial equation of the predicted response $(y)$ was proposed, which indicated coded independent variables $\left(X_{i}\right.$ and $X_{j}$ ) and their coefficients $\beta_{0}, \beta_{i}, \beta_{i i}$, and $\beta_{i j}$ as the coefficients for intercept, coefficient of linear effect, coefficient of quadratic effect, and coefficient of interaction effects, respectively, as given in Equation [1] (Myers, Montgomery, and AndersonCook, 2016).

$$
y=\beta_{0}+\sum_{i=1}^{n} \beta_{i} X_{i}+\sum_{i=1}^{n} \beta_{i i} X_{i}^{2}+\sum_{i=1}^{n} \sum_{j=i+1}^{n} \beta_{i j} X_{i} X_{j}+\varepsilon
$$

\section{Table II}

Fractional factorial design $\left(2^{5-1}\right)$ for experimental parameters (actual values)

\begin{tabular}{|c|c|c|c|c|c|}
\hline Run & IL type & IL concn. (\%) & Pulp density (\%) & $\mathrm{T}\left({ }^{\circ} \mathrm{C}\right)$ & Time (h) \\
\hline 1 & $\mathrm{BmimCF}_{3} \mathrm{SO}_{3}$ & $33 \%$ & $25 \%$ & 35 & 38 \\
\hline 2 & $\mathrm{BmimHSO}_{4}$ & $33 \%$ & $25 \%$ & 35 & 17 \\
\hline 3 & $\mathrm{BmimCF}_{3} \mathrm{SO}_{3}$ & $78 \%$ & $25 \%$ & 35 & 17 \\
\hline 4 & $\mathrm{BmimHSO}_{4}$ & $78 \%$ & $25 \%$ & 35 & 38 \\
\hline 5 & $\mathrm{BmimCF}_{3} \mathrm{SO}_{3}$ & $33 \%$ & $12.5 \%$ & 35 & 17 \\
\hline 6 & $\mathrm{BmimHSO}_{4}$ & $33 \%$ & $12.5 \%$ & 35 & 38 \\
\hline 7 & $\mathrm{BmimCF}_{3} \mathrm{SO}_{3}$ & $78 \%$ & $12.5 \%$ & 35 & 38 \\
\hline 8 & $\mathrm{BmimHSO}_{4}$ & $78 \%$ & $12.5 \%$ & 35 & 17 \\
\hline 9 & $\mathrm{BmimCF}_{3} \mathrm{SO}_{3}$ & $33 \%$ & $25 \%$ & 65 & 17 \\
\hline 10 & $\mathrm{BmimHSO}_{4}$ & $33 \%$ & $25 \%$ & 65 & 38 \\
\hline 11 & $\mathrm{BmimCF}_{3} \mathrm{SO}_{3}$ & $78 \%$ & $25 \%$ & 65 & 38 \\
\hline 12 & $\mathrm{BmimHSO}_{4}$ & $78 \%$ & $25 \%$ & 65 & 17 \\
\hline 13 & $\mathrm{BmimCF}_{3} \mathrm{SO}_{3}$ & $33 \%$ & $12.5 \%$ & 65 & 38 \\
\hline 14 & $\mathrm{BmimHSO}_{4}$ & $33 \%$ & $12.5 \%$ & 65 & 17 \\
\hline 15 & $\mathrm{BmimCF}_{3} \mathrm{SO}_{3}$ & $78 \%$ & $12.5 \%$ & 65 & 17 \\
\hline 16 & $\mathrm{BmimHSO}_{4}$ & $78 \%$ & $12.5 \%$ & 65 & 38 \\
\hline 17 & $\mathrm{BmimHSO}_{4}$ & $55.5 \%$ & $18.7 \%$ & 50 & 27.50 \\
\hline 18 & $\mathrm{BmimHSO}_{4}$ & $55.5 \%$ & $18.7 \%$ & 50 & 27.50 \\
\hline 19 & $\mathrm{BmimHSO}_{4}$ & $55.5 \%$ & $18.7 \%$ & 50 & 27.50 \\
\hline 20 & $\mathrm{BmimHSO}_{4}$ & $55.5 \%$ & $18.7 \%$ & 50 & 27.50 \\
\hline
\end{tabular}




\section{Using experimental design and response surface methodology (RSM) to optimize gold}

\section{Experimental}

A closed Schott bottle with $50 \mathrm{~mL}$ capacity was used as a leaching container for each experiment. Each particular sample was prepared with the appropriate amount of the pyrite flotation concentrate ( $-45 \mu \mathrm{m}$ fraction), thiourea, and iron (III) sulphate oxidant, added to a $10 \mathrm{~mL}$ mixture of imidazolium-based IL and deionized water with a specific IL concentration to obtain the required solid to liquid ratio based on the experimental design (see Table II). The $\mathrm{pH}$ of the IL-water mixture was adjusted to $\mathrm{pH}$ of 1 and a shaking speed of $250 \mathrm{r} / \mathrm{min}$ was used. To maintain a constant temperature, the bottles were incubated in a platform shaking incubator. The bottles were removed from the shaker at specified times, and the solutions filtered and the filtrates analysed for gold using AAS. The samples were thoroughly homogenized for each test to ensure the representativeness of the weighted samples corresponded to each other for every experiment. All experiments were run randomly to reduce the effects of an uncontrolled error (Montgomery, 1984) and repeated in triplicate to yield an average value for use in the calculations.

\section{Results and discussion}

\section{Significant factors}

The percentage of extracted gold in the leach liquor was calculated and used to evaluate both the main and interaction effects of the studied parameters. The estimation of the main effects and the interaction terms were illustrated in the halfnormal probability graph of gold extraction (Figure 5). As illustrated, all insignificant effects were typically spread with zero means and variance $\left(\sigma^{2}\right)$, and have a tendency to be along the straight line on the plot. On the contrary, significant effects were situated far away from the straight line with nonzero means. The greater the statistical significant effect, the greater the distance from the straight line. From this statistical analysis, the observed significant effects, in order of descending significance with respect to the influence on the desired measured response (percent extracted gold), were concentration of IL (B) $>$ temperature $(\mathrm{D})>$ solid to liquid ratio $(\mathrm{C})$. The interaction between the studied parameters were found to be insignificant since they all were located along the straight line on the halfnormal probability plot.

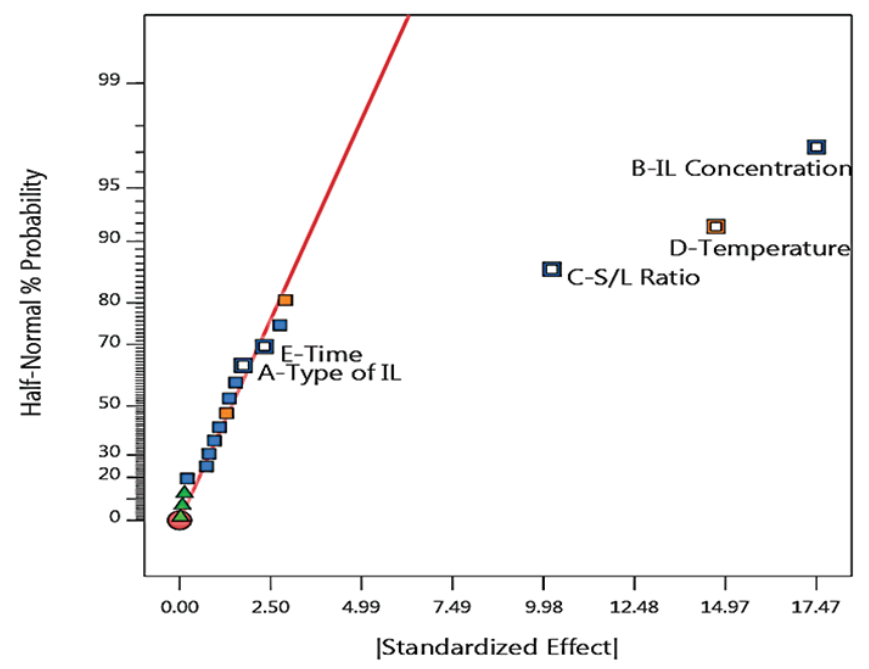

Figure 5-Half-normal plot of effects of the main and two-factor interactions

\section{Influence of factors on gold extraction}

\section{Effect of IL concentration}

The effect of IL concentration on gold extraction is presented in Figure 6. The ratios of $33 \%$ and $78 \%$ IL in aqueous solution were the low and high levels examined for this factor. As illustrated, higher extraction of gold was obtained at a lower IL concentration under the tested conditions. Pure ionic liquids are usually viscous, especially $\left[\mathrm{Bmim}^{+} \mathrm{HSO}_{4}^{-}\right](900 \mathrm{mPa})$ compared to water $(1 \mathrm{mPa})$, hence water was added to reduce the viscosity of the IL (Whitehead et al., 2007), thus improving the transport properties of the cations and anions in the system (Mawire and van Dyk, 2018). This was supported by the observed higher extraction of gold in the $33 \%$ IL solution, where the mass transfer was properties of the system were better than with $78 \%$ IL.

\section{Effect of pulp density}

The effect of pulp density (solid to liquid ratio) on gold extraction is illustrated in Figure 7. Under the investigated experimental conditions, a lower extraction was obtained at higher pulp density, which in this case was the pulp density of $25 \% \mathrm{w} / \mathrm{V}$ $(1: 4)$. The reduction in the gold extraction at higher pulp density can be attributed to the ineffective mixing of solids and the liquid solution (IL-water mixture) as a result of the mixture's high density, which leads to ineffective mass transfer. In contrast, higher gold extraction was obtained at a lower pulp density of $12.5 \% \mathrm{w} / \mathrm{V}(1: 8)$.

\section{Effect of temperature}

Figure 8 demonstrates the effect of temperature on gold extraction. It can be seen that more gold was extracted at a higher temperature under the conditions tested. The viscosity of IL generally follows the Vogel-Fulcher-Tammann (VFT) expression and the temperature dependence of viscosity can be described

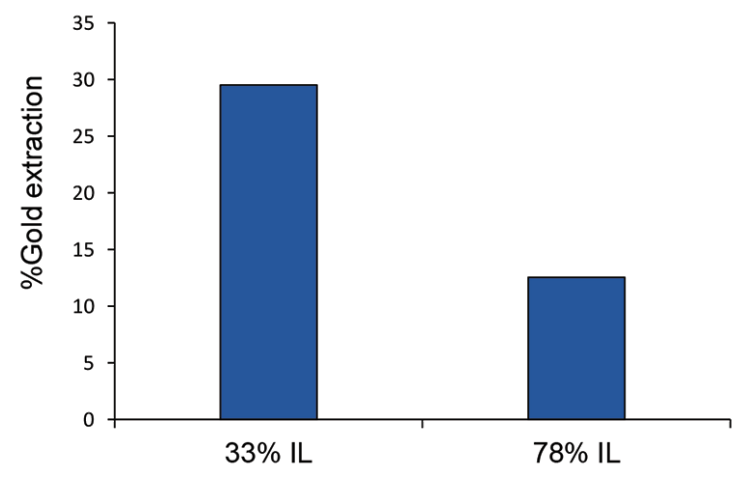

Figure 6-Effect of IL concentration on gold extraction

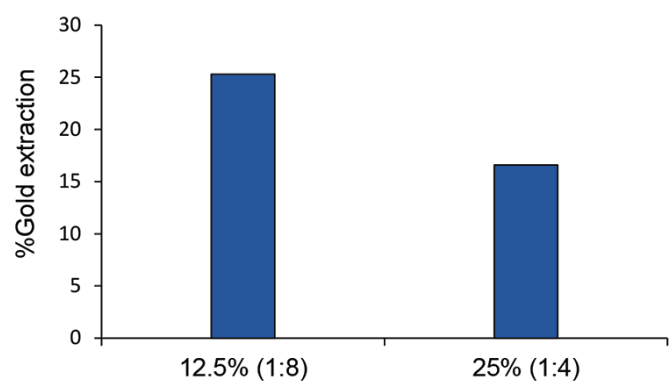

Figure 7-Effect of solid to liquid ratio on gold extraction 


\section{Using experimental design and response surface methodology (RSM) to optimize gold}

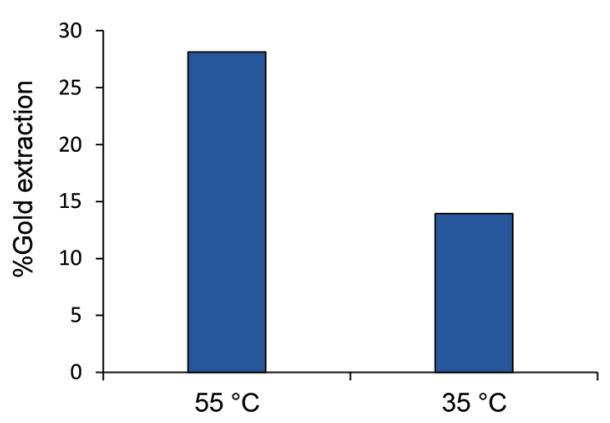

Figure 8-Effect of temperature on gold extraction

by the Arrhenius equation (Mawire and van Dyk, 2018). The viscosity of the IL-water system decreases with an increase in temperature and, as mentioned earlier, high viscosity adversely affects extraction in this system. In addition, higher gold extraction at higher temperature can be expected since thiourea has fast kinetics for gold dissolution (Örgül and Atalay, 2002). Likewise, at higher temperatures more collisions occur between reactant molecules with adequate energy during oxidative leaching.

\section{Optimization of significant parameters}

\section{Experimental design for the response surface methodology and central composite design}

Optimization of the statistically influential parameters on the measured response (yield of gold) was examined. From the screening tests, it was observed that the IL concentration, pulp density, and temperature were statistically significant parameters in gold extraction from concentrated gold-bearing pyrite using the mixture of IL aqueous solution/thiourea/ ferric ions. Further experiments were done by focusing on these three influential parameters inside the experimental area to optimize the extraction of gold by employing CCD and RSM techniques. In addition, since both ILs studied, [Bmim+ $\left.\mathrm{HSO}_{4}^{-}\right]$and $\left[\mathrm{Bmim}^{+} \mathrm{CF}_{3} \mathrm{SO}_{3}^{-}\right]$, could extract gold, one of the ILs $\left(\left[\mathrm{Bmim}^{+} \mathrm{HSO}_{4}^{-}\right]\right)$was used for further experiments in the optimization stage.

The designed procedure for the CCD and RSM optimization in this study was as follows:
(1) Designing and conducting a series of experiments in order to obtain reliable measurements of the response (gold extraction)

(2) Developing a mathematical model

(3) Establishing the optimal experimental parameters

(4) Demonstrating the effects of significant studied parameters through three-dimensional (3D) plots (Myers, Montgomery, and Anderson-Cook, 2016).

\section{Derivation of the fitted model}

The fitted second-order coded model with the variable terms that were significant at greater or equal to $95 \%$ confidence level was obtained as shown in Equation [2]:

$$
\begin{aligned}
& y=30.71-1.65 x_{1}-3.06 x_{2}+0.52 x_{3}-1.42 x_{1}{ }^{2}-2.78 x_{2}{ }^{2} \\
& -1.49 x_{3}{ }^{2}-1.65 x_{1} x_{2}+1.40 x_{1} x_{3}-1.60 x_{2} x_{3}
\end{aligned}
$$

where, $y$ is the predicted response for gold, $x_{1}, x_{2}$, and $x_{3}$ the coded levels of process variables (IL concentration, pulp density, and temperature, respectively) within the predictor variable limits: $-\lambda \leq x_{i} \leq+\lambda ; \mathrm{i}=1,2,3$, and $\lambda=2^{(\mathrm{k}) 1 / 4}=1.682$ (for $\mathrm{k}=3$ ); where $\lambda$ is the distance between the star points and the centre of the $\mathrm{CCD}$, and $\mathrm{k}$ is the number of factors.

\section{Checking the adequacy of the developed model}

The adequacy of the fitted model was tested by applying analysis of variance (ANOVA), F-value, P-value, and coefficient of determination $\left(\mathrm{R}^{2}\right)$ at $95 \%$ confidence level. Table IV represents the results for an ANOVA for the fitted model. Statistically at this level of confidence, a probability value (P-value) less than 0.050 indicates that the model terms were significant, while values greater than 0.100 indicate that the model terms were insignificant. Thus, the results revealed that the fitted regression model was significant with a P-value of 0.0001 . However, the lack of fit was insignificant with a P-value of 0.333 .

\section{Table $V$}

\section{Fitted summary statistics}

\begin{tabular}{|l|r|r|r|}
\hline Std. dev. & 1.41 & $R^{2}$ & 0.9549 \\
Mean & 26.52 & Adjusted $R^{2}$ & 0.9144 \\
CV (\%) & 5.31 & Predicted $R^{2}$ & 0.7626 \\
& & Adeqate precision & 15.5807 \\
\hline
\end{tabular}

\section{Table IV}

\begin{tabular}{|c|c|c|c|c|c|}
\hline Source & Sum of squares & df & Mean square & F-value & P-value \\
\hline Model & 420.00 & 9 & 46.67 & 23.55 & 0.0001 \\
\hline A (IL concentration) & 43.69 & 1 & 43.69 & 22.04 & 0.0008 \\
\hline B (pulp density) & 131.17 & 1 & 131.17 & 66.18 & 0.0001 \\
\hline C (temperature) & 3.98 & 1 & 3.98 & 2.01 & 0.0186 \\
\hline$A B$ & 21.78 & 1 & 21.78 & 10.99 & 0.0078 \\
\hline$A C$ & 15.78 & 1 & 15.78 & 7.96 & 0.0181 \\
\hline$B C$ & 20.51 & 1 & 20.51 & 10.35 & 0.0092 \\
\hline$A^{2}$ & 51.93 & 1 & 51.93 & 26.20 & 0.0005 \\
\hline$B^{2}$ & 121.90 & 1 & 121.90 & 61.50 & 0.0001 \\
\hline $\mathrm{C}^{2}$ & 39.01 & 1 & 39.01 & 19.68 & 0.0013 \\
\hline Residual & 19.82 & 10 & 1.98 & & \\
\hline Lack of fit & 11.90 & 5 & 2.38 & 1.50 & 0.3330 \\
\hline Pure error & 7.92 & 5 & 1.58 & & \\
\hline Total & 439.82 & 19 & & & \\
\hline
\end{tabular}

\section{ANOVA for the fitted model}




\section{Using experimental design and response surface methodology (RSM) to optimize gold}

From the fitted summary statistics presented in Table V, the low standard deviation value of 1.41 and high $\mathrm{R}^{2}$ value of 0.95 indicate that the model was statistically likely to accurately define the performance of the experimental system.

Experimental results and predicted values obtained using the fitted models are presented in Table VI. The predicted values were reasonably comparable to the experimental values, with a linear correlation coefficient of $\mathrm{R}^{2}=0.97$ (Figure 9).

\section{Response surface methodology}

Once the experimental area was confined, the IL concentration (factor A), pulp density (factor B), and temperature (factor C) were fine-tuned using RSM by evaluating two parameters at the same time while holding the other constant at the centre level.

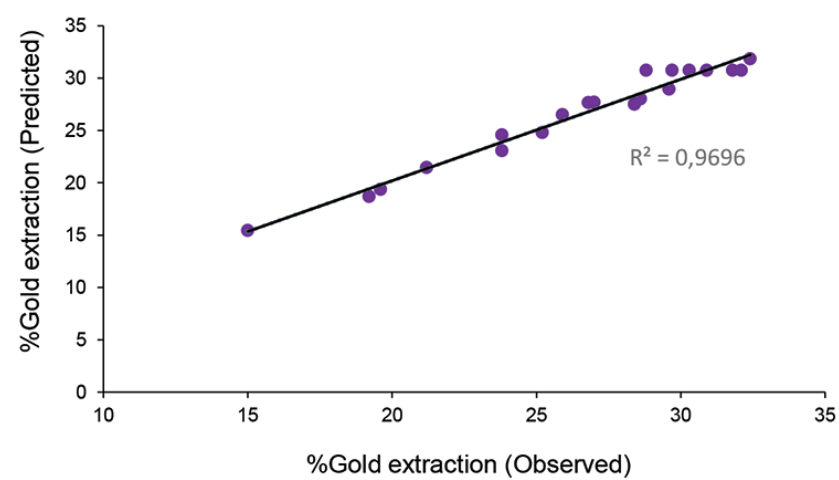

Figure 9-Relationship between experimental and predicted values for gold extraction
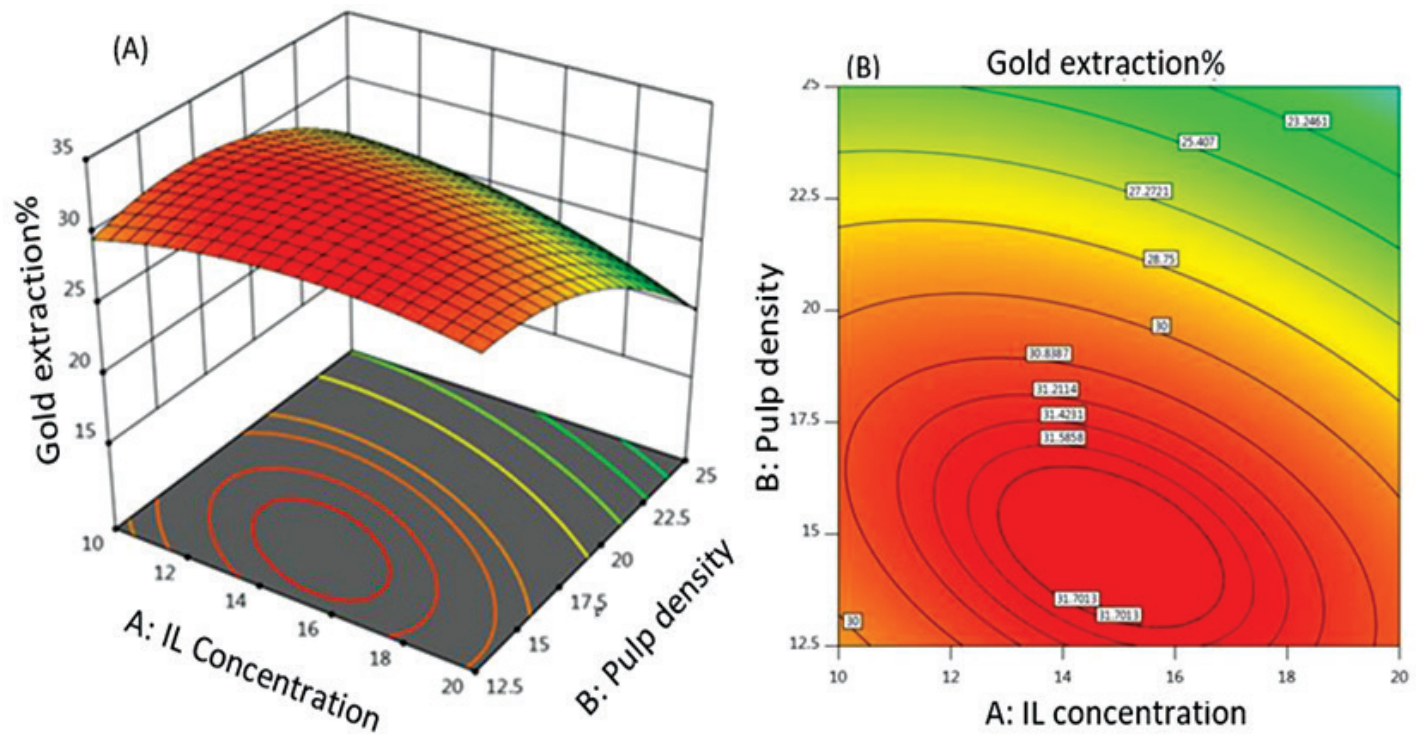

Figure 10-(A) Surface and (B) contour plots showing the effect of IL concentration and pulp density on gold extraction at $50^{\circ} \mathrm{C}$

\begin{tabular}{|c|c|c|c|c|c|}
\hline \multirow[t]{2}{*}{ Standard run } & \multicolumn{3}{|c|}{ Actual levels of factors } & \multirow[t]{2}{*}{ Au yield (observed) } & \multirow[t]{2}{*}{ Au yield (predicted) } \\
\hline & A IL concn. & B Pulp density & C Temperature & & \\
\hline \multicolumn{6}{|l|}{ Factorial points } \\
\hline 1 & 10 & 12.5 & 35 & 28.4 & 27.36 \\
\hline 2 & 20 & 12.5 & 35 & 19.21 & 18.71 \\
\hline 3 & 10 & 25 & 35 & 28.40 & 27.51 \\
\hline 4 & 20 & 25 & 35 & 25.23 & 24.81 \\
\hline 5 & 10 & 12.5 & 60 & 23.80 & 23.07 \\
\hline 6 & 20 & 12.5 & 60 & 19.60 & 19.36 \\
\hline 7 & 10 & 25 & 60 & 29.60 & 28.94 \\
\hline 8 & 20 & 25 & 60 & 32.40 & 31.85 \\
\hline \multicolumn{6}{|l|}{ Axial points } \\
\hline 9 & 5 & 18.75 & 48 & 26.76 & 27.62 \\
\hline 10 & 25 & 18.75 & 48 & 21.17 & 21.45 \\
\hline 11 & 15 & 30 & 48 & 15.00 & 15.46 \\
\hline 12 & 15 & 8 & 48 & 27.00 & 27.69 \\
\hline 13 & 15 & 18.75 & 25 & 23.82 & 24.62 \\
\hline 14 & 15 & 18.75 & 70 & 25.88 & 26.49 \\
\hline \multicolumn{6}{|l|}{ Centre points } \\
\hline 15 & 15 & 18.75 & 48 & 32.15 & 30.75 \\
\hline 16 & 15 & 18.75 & 48 & 31.76 & 30.75 \\
\hline 17 & 15 & 18.75 & 48 & 28.82 & 30.75 \\
\hline 18 & 15 & 18.75 & 48 & 30.88 & 30.75 \\
\hline 19 & 15 & 18.75 & 48 & 30.30 & 30.75 \\
\hline 20 & 15 & 18.75 & 48 & 29.71 & 30.75 \\
\hline
\end{tabular}




\section{Using experimental design and response surface methodology (RSM) to optimize gold}

Figure 10 shows response surface (3D) and contour plots (2D), where gold extraction was represented by simultaneously varying the $\mathrm{IL}\left[\mathrm{Bmim}^{+} \mathrm{HSO}_{4}^{-}\right]$concentration from $10 \%$ to $20 \%$ $(\mathrm{v} / \mathrm{v})$ and pulp density from 12.5 to $25(\mathrm{w} / \mathrm{v})$ at a temperature of $50^{\circ} \mathrm{C}$. The lines of the contour plots represent the values of gold extraction for different IL concentrations and pulp densities at an extraction time of 24 hours. The optimum condition was found as the red shaded area where the pulp density of $14 \%$ to $16 \%$ (w/v) converges with the concentration of IL between 14\% to 16\% (v/v) in the IL aqueous sample. In other words, to obtain a higher gold extraction, the leach solution should be prepared at around the centre point of IL concentration (15\% v/v) and pulp density $(15 \% \mathrm{w} / \mathrm{v})$. The results imply that there was effective homogeneous mixing of solids and liquid at low pulp density, leading to better mass transfer and hence increased gold extraction. Also, at low IL concentration the viscosity of the ILwater mixture was low, which enhances gold extraction.

Figure 11 illustrates the effect of IL $\left[\mathrm{Bmim}^{+} \mathrm{HSO}_{4}^{-}\right]$ concentration and temperature on gold extraction at the centre level of pulp density $(18.75 \mathrm{w} / \mathrm{v})$ for 24 hours leaching time. The IL concentration was varied from $10 \%$ to $20 \%(\mathrm{v} / \mathrm{v}$ ) and the temperature varied from 35 to $60^{\circ} \mathrm{C}$. It can be seen that gold extraction was at its maximum value in $15 \%(\mathrm{v} / \mathrm{v})$ IL at an elevated temperature in the range of $55-60^{\circ} \mathrm{C}$. The viscosity of IL $\left[\mathrm{Bmim}^{+} \mathrm{HSO}_{4}^{-}\right]$in water reduces at high temperature, resulting in free ions as well as more collisions between reactant molecules, which leads to better gold extraction. Besides, at higher temperatures the reaction kinetics of thiourea was faster for extracting gold in the system (Örgül and Atalay, 2002).

Figure 12 displays the effect of pulp density and temperature on gold extraction at constant IL $\left[\mathrm{Bmim}^{+} \mathrm{HSO}_{4}^{-}\right]$concentration at the central level $(15 \% \mathrm{v} / \mathrm{v})$ over a period of 24 hours. Gold extraction increased with a decrease in pulp density and increase in temperature. The optimum condition was found as the red shaded area which converges at the values from $14 \%$ to $15 \%$ $(\mathrm{w} / \mathrm{v})$ for the pulp density and around a temperature of $55-60^{\circ} \mathrm{C}$. Increasing the temperature and decreasing the pulp density reduce the viscosity of the IL-water solution and thus contributed to better mass transfer which results in increased gold extraction.

\section{Confirmatory experiments}

To test the validity of the optimized conditions achieved by the RSM, experiments were carried out with the parameters at the
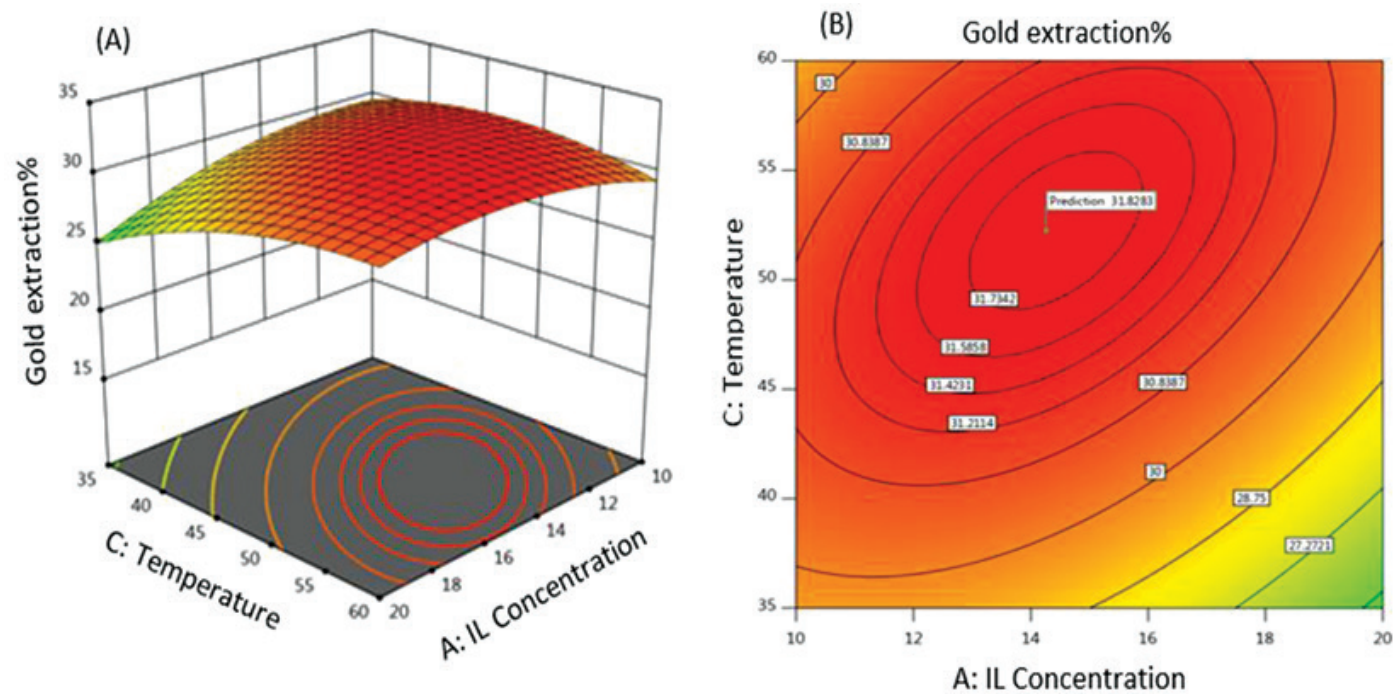

Figure 11-(A) Surface and (B) contour plots showing the effect of IL $\left[\mathrm{Bmim}^{\left.+\mathrm{HSO}_{4}-\right]}\right.$ concentration and temperature on gold extraction at a pulp density of $18.75(\mathrm{w} / \mathrm{v})$
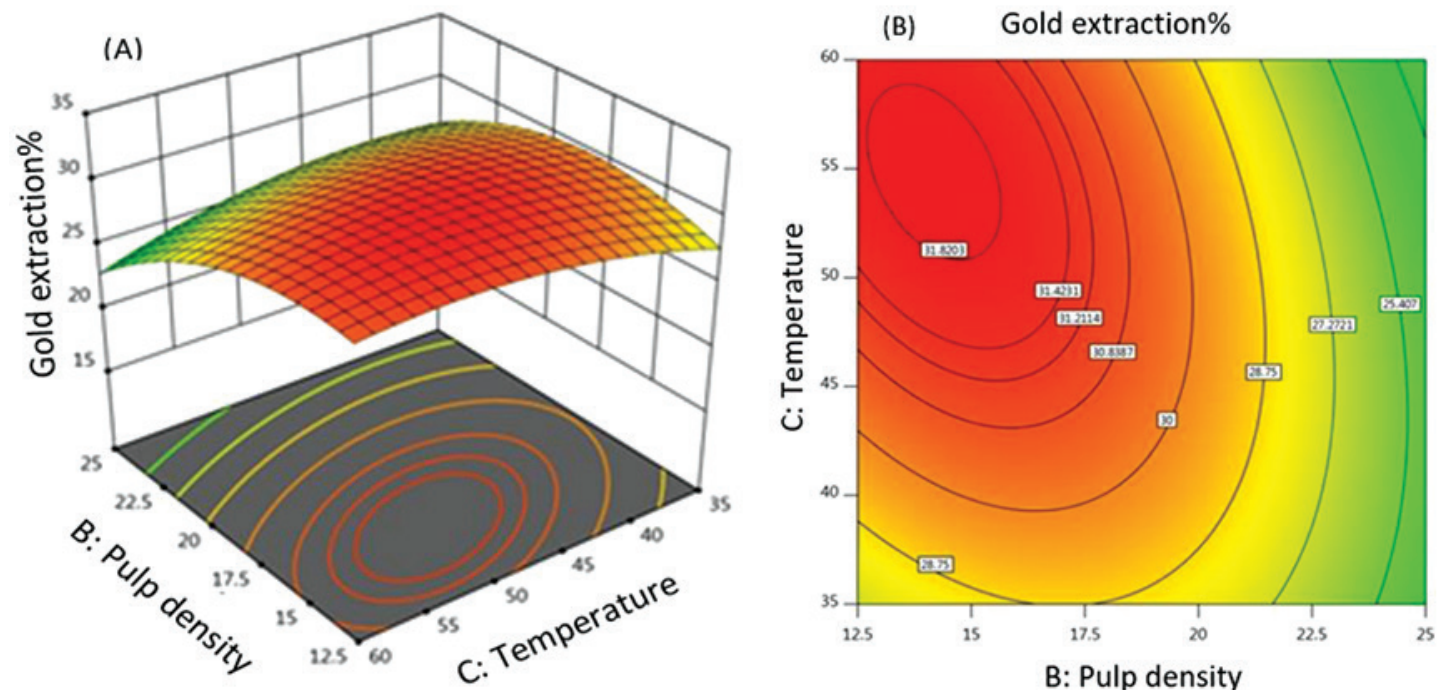

Figure 12-(A) Surface and (B) contour plots showing the effect of interaction of pulp density and temperature on gold extraction at $15 \%(\mathrm{~V} / \mathrm{v})$. [Bmim+ $\left.\mathrm{HSO}_{4}^{-}\right]$ 


\section{Using experimental design and response surface methodology (RSM) to optimize gold}

levels indicated. The conditions were as follows: $\mathrm{IL}\left[\mathrm{Bmim}^{+} \mathrm{HSO}_{4}^{-}\right]$ $15 \%(\mathrm{v} / \mathrm{v})$, pulp density $15 \%(\mathrm{w} / \mathrm{v})$, and temperature $60^{\circ} \mathrm{C}$. The gold extraction under optimum experimental conditions for 24 hours leaching time was found to be $35.7 \%$ which, within experimental error, is consistent with the model, which predicted $35.2 \%$ extraction (Table VII). The model can, therefore, be considered to fit the experimental data under the experimental conditions.

\section{Conclusions}

The identification of statistically influential parameters in the extraction of gold from refractory sulphidic gold sample with a mixture of IL aqueous solution/thiourea/ferric ion was addressed by screening the main parameters using a half-fractional factorial design. The experimental results were analysed statistically for the significance of the studied parameters using the probability plot. It was found that IL concentration, pulp density, and temperature were statistically significant parameters, while the type of IL and extraction time did not affect the gold extraction as much. The significant parameters were optimized by applying CCD and RSM to find the optimum experimental conditions.

The optimum gold extraction conditions for the IL leaching system according to the RSM were IL $\left[\mathrm{Bmim}^{+} \mathrm{HSO}_{4}^{-}\right] 15 \%(\mathrm{v} / \mathrm{v})$, pulp density $15 \%(\mathrm{w} / \mathrm{v})$, and temperature $60^{\circ} \mathrm{C}$. A confirmatory test was carried out under the optimum conditions and achieved a gold extraction of $35.7 \%$, whereas the model predicted $35.2 \%$ extraction under the same conditions. The closeness of the confirmatory test results to the predicted value shows that the model fits the experimental data reasonably well.

The results obtained indicated the following.

> The selected statistical method and experimental design approach were able to help in determining statistically significant and insignificant parameters for gold extraction. The half-normal probability chart statistically identified the significant parameters as IL concentration, pulp density, and temperature.

> The high $\mathrm{R}^{2}$ values signify that the model obtained was able to give a reasonably good estimate of the response values in the studied range.

> Optimal gold extraction of $35.7 \%$ was achieved at an IL $\left[\mathrm{Bmim}^{+} \mathrm{HSO}_{4}^{-}\right]$concentration of $15 \%(\mathrm{v} / \mathrm{v})$, pulp density $15 \%(\mathrm{w} / \mathrm{V})$, and temperature of $60^{\circ} \mathrm{C}$.

> The model can be considered to fit the experimental data very well under the experimental conditions studied.

The IL contribution was observed in a specific range, since the addition of $15-20 \%(\mathrm{v} / \mathrm{v}) \mathrm{IL}\left[\mathrm{Bmim}^{+} \mathrm{HSO}_{4}^{-}\right]$in water can create the acidic environment required for thiourea leaching by releasing protons $\left(\mathrm{H}^{+}\right)$, which is in agreement with the investigation by Aguirre et al. (2016). Equilibrium studies of the release of protons from IL $\left[\mathrm{Bmim}^{+} \mathrm{HSO}_{4}^{-}\right]$in aqueous solution have been reported by Crowhurst et al. (2003) and Dong et al. (2009).

\section{Table VII}

\section{Gold extraction at optimal conditions}

\begin{tabular}{|l|c|c|c|c|}
\hline Parameters & $\begin{array}{c}\text { IL } \\
\text { [Bmim+HSO }\end{array}{ }_{4}^{-]}$ & $\begin{array}{c}\text { Pulp } \\
\text { density }\end{array}$ & Temperature & $\begin{array}{c}\% \\
\text { extraction }\end{array}$ \\
\hline Model & $15 \%(\mathrm{v} / \mathrm{v})$ & $15 \%(\mathrm{w} / \mathrm{v})$ & $60^{\circ} \mathrm{C}$ & 35.2 \\
Confirmatory tests & $15 \%(\mathrm{v} / \mathrm{v})$ & $15 \%(\mathrm{w} / \mathrm{v})$ & $60^{\circ} \mathrm{C}$ & 35.7 \\
\hline
\end{tabular}

It should be noted that although the cyanide leaching was done on finely milled pyrite flotation concentrate, the concentrate sample used was not as fine as that used in the cyanide leaching process. This may be one of the reasons for the lower gold extraction. Therefore, further detailed work on the leaching of refractory sulphidic ore containing gold using ILs needs to be undertaken to identify the factors that can achieve higher gold extraction.

\section{Acknowledgements}

The authors gratefully acknowledge the financial support of DRDGOLD (Pty.) Ltd in conducting this work. The School of Chemical and Metallurgical Engineering at the University of the Witwatersrand is thanked for supplying laboratory facilities and technical support.

\section{References}

Aguirre, C.L., Toro, N., CArvajal, N., Watuing, H., and Aguirre, C. 2016. Leaching of chalcopyrite $\left(\mathrm{CuFeS}_{2}\right)$ with an imidazolium-based ionic liquid in the presence of chloride. Minerals Engineering, vol. 99 (May). pp. 60-66. https://doi. org/10.1016/j.mineng.2016.09.016

АттіA, Y.A. and EL-Zеку, M. 1989. Bioleaching of gold pyrite tailings with adapted bacteria. Hydrometallurgy, vol. 22, no. 3. pp. 291-300. https://doi. org/10.1016/0304-386X(89)90026-1

Crowhurst, L., Mawdsley, P.R., Perez-Arlandis, J.M., Salter, P.A., and Welton, T. 2003. Solvent-solute interactions in ionic liquids. Physical Chemistry Chemical Physics, vol. 5, no. 13. pp. 2790-2794. https://doi.org/10.1039/b303095d

Dong, T., HuA, Y., ZHANG, Q., and ZHou, D. 2009. Leaching of chalcopyrite with Brønsted acidic ionic liquid. Hydrometallurgy, vol. 99, no. 1-2. pp. 33-38. https://doi.org/10.1016/j.hydromet.2009.06.001

Falagán, C., Grail, B.M., and Johnson, D.B. 2017. New approaches for extracting and recovering metals from mine tailings. Minerals Engineering, vol. 106. pp. 71-78. https://doi.org/10.1016/j.mineng.2016.10.008

Grosse, A.C., Dicinoski, G.W., Shaw, M.J., and Haddad, P.R. 2003. Leaching and recovery of gold using ammoniacal thiosulfate leach liquors (a review). Hydrometallurgy, vol. 69, no. 1-3. pp. 1-21. https://doi.org/10.1016/S0304386X(02)00169-X

LEE, J.-M. 2012. Extraction of noble metal ions from aqueous solution by ionic liquids. Fluid Phase Equilibria. https://doi.org/10.1016/j.fluid.2012.01.033

MAwiRE, G. and van Dyк L. 2018. Extraction of Scandium (Sc) Using a Task-Specific Ionic Liquid Protonated Betaine Bis(Trifluoromethylsulfonyl)Imide [Hbet] [Tf2N]. Davis, B. et al. (eds) Extraction 2018. The Minerals, Metals \& Materials Series. Springer, Cham.

Montgomery, D.C. 1984. Design and Analysis of Experiments. 8th edn. Wiley, New York.

Myers, R.H., Montgomery, D.C., and Anderson-Cook, M.C. 2016. Response Surface Methodology: Process and Product Optimization Using Designed Experiments. Wiley Series in Probability and Statistics. https://doi.org/10.1017/ CBO9781107415324.004

ÖRGÜL, S. and ATALAY, Ü. 2002. Reaction chemistry of gold leaching in thiourea solution for a Turkish gold ore. Hydrometallurgy, vol. 67, no. 1-3. pp. 71-77. https://doi.org/10.1016/S0304-386X(02)00136-6

Park, J., Jung, Y., Kusumah, P., Lee, J., Kwon, K., and Lee, C.K. 2014. Application of ionic liquids in hydrometallurgy. International Journal of Molecular Sciences, vol. 15, no. 9. pp. 15320-15343. https://doi.org/10.3390/ijms150915320

Shemi, A., Ndlovu, S., Sibanda, V., and van Dyк, L.D. 2013. Extraction of aluminium from coal fly ash : Identification and optimization of influential factors using statistical design of experiments. International Journal of Mineral Processing, vol. 127. pp. 10-15.

Simate, G.S., NdLovu, S., and Gericke, M. 2009. Bacterial leaching of nickel laterites using chemolithotrophic microorganisms: Process optimisation using response surface methodology and central composite rotatable design. Hydrometallurgy, vol. 98, no. 3-4. pp. 241-246. https://doi.org/10.1016/j.hydromet.2009.05.007

Teimouri, S., Potgieter, J.H., Simate, G.S., van Dyk, L., and Dworzanowski, M. 2020. Oxidative leaching of refractory sulphidic gold tailings with an ionic liquid. Minerals Engineering, vol. 156 (May). https://doi.org/10.1016/j. mineng.2020.106484

Whitehead, J.A., Zhang, J., McCluskey, A., and Lawrance, G.A. 2009. Comparative leaching of a sulfidic gold ore in ionic liquid and aqueous acid with thiourea and halides using $\mathrm{Fe}(\mathrm{III})$ or $\mathrm{HSO}_{5}$ - oxidant. Hydrometallurgy, vol. 98, no. 3-4. pp. 276-280. https://doi.org/10.1016/j.hydromet.2009.05.012

Whitehead, J.A., Zhang, J., Pereira, N., McCluskey, A., and Lawrance, G.A. 2007. Application of 1-alkyl-3-methyl-imidazolium ionic liquids in the oxidative leaching of sulphidic copper, gold and silver ores. Hydrometallurgy, vol. 88, no. 1-4. pp. 109-120. https://doi.org/10.1016/j.hydromet.2007.03.009

Whitehead, J.A., LaWrance, G.A., and McCluskey, A. 2004. "Green" leaching: Recyclable and selective leaching of gold-bearing ore in an ionic liquid. Green Chemistry, vol. 6, no. 7. pp. 313-315. https://doi.org/10.1039/b406148a 